\title{
SUSTAINABLE DEVELOPEMENT IN LOGISTIC - A STRATEGY FOR MANAGEMENT IN TERMS OF GREEN TRANSPORT
}

\author{
Dorota KLIMECKA-TATAR, Manuela INGALDI \\ Częstochowa University of Technology \\ Matevž OBRECHT \\ University of Maribor
}

\begin{abstract}
:
Supply chain management is one of the most important elements of sustainable development. And due to the fact that the world market is driven by supply and demand, and the determinant of access to products is regional and international logistics, this paper focuses on the possibilities of implementing a green transport strategy in the context of sustainable development in logistic enterprises. This paper presents the results of the SWOT analysis pointing out the strengths, weaknesses, opportunities, threats of green vehicles market for the transport enterprises. It was noticed that the situation on the green vehicles market for the transport enterprises is characterized by the advantage of strengths and these strengths should be used to maximize the use of green vehicles. It emphasized that subsidies for green vehicles would allow to invest in a modern fleet, new solutions (e.g. own charging stations) can have an impact on the greater energy efficiency (self-sufficiency), increase of social awareness would force enterprises to take appropriate actions in the field of environmental protection and development of public transport based on green vehicles.
\end{abstract}

Key words: SWOT analysis, sustainable development, green transport, green logistics, sustainability

\section{INTRODUCTION}

The logistics (as a significant element in supply chain management) is one of the industry branch that have a significant impact on the increased production of carbon dioxide, and thus on air pollution. For several decades, research, strategic, social and structural activities have been carried out, the main purpose of which is to answer the bothering question - how, in a strongly developing economy and industry, to minimize the negative impact of humans on the environment (especially when this development is based on energy supplies).

One of the methods of caring for the environment are the constantly growing requirements in the field of environmental policy in Europe and in the world, which results in the multiplication of new technologies and possibilities (innovations) in the field of regional and international transport. Minimizing environmental pollution is a priority of the environmental policy that applies until 2050 [1, 2]. Such activities within the law and policy, as early as at the end of the $20^{\text {th }}$ century, but especially in the second decade of the $21^{\text {st }}$ century, resulted in a dynamic development in the field of "green" fuels in road, rail and sea transport [3]. As shown by numerous very interesting studies, it is very difficult to change the attitude of citizens to new, often unknown fuel technologies. Therefore, it is suggested to start changes by changing the attitude of entrepreneurs to technologies favoring environmental protection.

\section{LITERATURE REVIEW}

Supply chain management is one of the most important elements of sustainable development. This is due to the fact that both the logistics itself and the supply chain, in order to adapt and mitigate business logistics, should be oriented towards the protection of resources and care for the environment - towards the green transport $[4,5,6,7,8]$. Green transport is an element of green logistics and is defined as the management of supplies (materials and products) that reduces the environmental and energy footprint of the distributed goods. Green Transport involves an organization's activities that take environmental considerations into account and integrate it into supply chain management to change the environmental performance of suppliers and customers [9].

To address the significant contribution of transport (professional transport) to greenhouse gas emissions, the government continues to develop a green transport strategy 
(GTS). The main goal of green transport is to minimize the negative impact of transport on the environment, while taking into account current and future transport needs. One of the tools of the green transport strategy is also encouraging the implementation of modern technologies. Activities related to ecological transport also include monitoring the involvement of entrepreneurs in the development of green technologies [2].

Because the implementation of the concept of sustainable development remains the greatest challenge in the world, it is even more important to understand what elements should be given special attention [10, 11]. All kinds of changes are particularly difficult to introduce in small and medium-sized enterprises, where global management trends are often ignored. There are many problems when implementing new technologies and concepts in sustainable enterprise management (and not only logistics), ranging from organizational (management) barriers, through the enterprise culture and social attitude to the upcoming changes $[12,13,14]$.

As the Klimecka-Tatar and Ingaldi (2020) point out, there are many barriers that cause a negative attitude to changes in habits with regard to the use of energy sources $[15,16]$. Such barriers are visible in almost all technological changes - not only in the concepts of technological development, but also in the concept of the Industry 4.0 strategy or the Lean concept $[17,18,19,20,21]$.

The social barrier seems to be the most difficult to break. Social resistance, which may result in the lack of acceptance of the introduced changes, is the most frequent cause of delay in investments and industrial innovations. The mental barrier is also closely related to the previous one. The source of the mental barrier can be found in the lack of knowledge (or insufficient knowledge) in a given topic. Obviously, various types of social campaigns seem to be helpful in this respect, and they should be supported by earlier research identifying the causes of social resistance. In order to increase the awareness of the society (including the entrepreneurs themselves), it is necessary to introduce a knowledge management strategy from a global perspective - with the delineation of areas for improvement [22, 23, 24, $25,26]$.

The third but key barrier is the economic barrier. The economic barrier itself is a very big problem in the concept of sustainable development in supply chain management. This barrier may, by its strength, hinder development in many areas. What is more, it can often become a support for building social and mental resistance. The lack of financial resources is a very big problem in the implementation of innovations and modern technologies. In this regard, social programs/projects (previously discussed) financed from national or international funds (often supported by the European Union) are helpful [2, 27].

For transport companies, one of the major changes to green management may be the modernization of the transport fleet. This modernization should of course be understood as not rejuvenating the fleet (i.e. the purchase of new cars running on petroleum fuels), but most of all retrofitting vehicles with the latest energy solutions. And the total or gradual elimination of diesel and gasoline cars. Green cars include, first of all, hybrid, electric and hydrogen-powered cars, as well as the increasingly popular V2G (vehicle to grid) cars [28, 29, 30, 31, 32, 33]. Replacing the fleet with the so-called green fleet obviously requires a lot of commitment on the part of the entrepreneur in environmental strategies. Apart from extensive knowledge and ecological maturity, it unfortunately requires quite a significant capital contribution.

As it is easy to see on the market, cars belonging to the prestigious group of green cars are quite expensive investments. For example, class A electric cars often represent a cost similar to a poorly equipped $S$ class car, which unfortunately discourages entrepreneurs. In many countries, in order to break the GTS economic barrier, numerous structural programs are introduced. These programs include quite substantial subsidies (e.g. 30\% in Poland) for the purchase of brand new electric cars. For example, the eVAN program has appeared on the European market, the main goal of which is to minimize air pollutant emissions by supporting the purchase of delivery vehicles using electric power. The program includes, apart from the possibility of purchasing electric vans, also the possibility of co-financing the purchase of a charging point with a power of up to 22 $\mathrm{kW}$ (without the possibility of providing charging services). At the same time, the conditions for obtaining the subsidy are not very simple.

Therefore, the purpose of this paper is to indicate areas that in logistics companies constitute the basis for bidding a wall against sustainable development (in this case in the use of energy sources).

\section{METHODOLOGY OF RESEARCH}

A SWOT analysis was carried out in order to define the strategy related to the development of green vehicles, especially their use in a fleet of various types of logistic enterprises. Usually, this analysis is used to verify the strategic position of enterprises within their operations [34]. However, as many studies was shown, that it can also be used to check the achievement of sustainable development goals [35] or prioritizing sustainable urban regeneration in sensitive areas [36], which points to its universality.

Based on the literature data $[8,9,15,37,38,39,40,41,42$, $43]$, the main factors for individual groups of the analysis were determined, i.e. strengths, weaknesses, opportunities, threats. Next, assessment and weights were determined for each factor. The assessment of individual factors influencing the strategy was made on a scale from 1 to 5 , where 1 means little impact, and 5 very strong impact. The weights signified the importance of individual

factors, their sum of weights in each group should be 1 . This method was used to balance different numbers of factors in particular groups. The product of assessment and weight for the individual factors was calculated and then summed up in the groups. On the basis of these sums, the strategic position of the strategy related to the development of green vehicles was determined. Subsequently, it was proposed how to use a specific strategy so that it brings the greatest possible effect. 
It should be remembered that the conducted analysis is an authorial discussion, which is caused by the debate on the growing importance of the use of green vehicles. It is based on currently available information on the topic under study.

\section{RESULTS OF RESEARCH}

The SWOT analysis allows determining the strategic position of the green vehicles strategy in transport enterprises. Tables 1-4 present the classification of each group of factors having an influence on the strategic position related to green vehicles.

Table 1 Classification of strengths of the green vehicles

\begin{tabular}{|c|c|c|c|c|}
\hline 운 & Strengths & 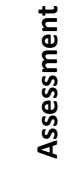 & $\frac{\stackrel{+}{\frac{10}{00}}}{\sum_{3}^{2}}$ & 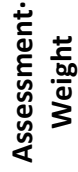 \\
\hline S1 & A wide selection of electric vehicles & 3 & 0.05 & 0.15 \\
\hline S2 & A possibility of using hydrogen vehicles & 3 & 0.05 & 0.15 \\
\hline S3 & Less noise from electric vehicles & 5 & 0.1 & 0.5 \\
\hline S4 & Less exhaust emissions & 5 & 0.15 & 0.75 \\
\hline S5 & Greater energy efficiency & 4 & 0.1 & 0.4 \\
\hline S6 & Environmentally friendly vehicles & 5 & 0.1 & 0.5 \\
\hline S7 & Improving air quality & 5 & 0.15 & 0.75 \\
\hline S8 & High driving comfort & 4 & 0.05 & 0.2 \\
\hline S9 & $\begin{array}{l}\text { Greater energy self-sufficiency in case } \\
\text { of the } V 2 G \text { fleet }\end{array}$ & 4 & 0.1 & 0.4 \\
\hline S10 & Development of green logistic chain & 4 & 0.05 & 0.2 \\
\hline \multirow{2}{*}{\multicolumn{2}{|c|}{ S11 Increasing Corporate Social Responsibility }} & 4 & 0.1 & 0.4 \\
\hline & & Sum & 1 & 4.4 \\
\hline
\end{tabular}

Table 2

Classification of weaknesses of the green vehicles

\begin{tabular}{|c|c|c|c|c|}
\hline 2 & Weaknesses & 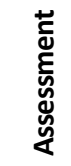 & 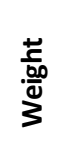 & 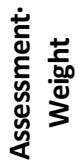 \\
\hline W1 & Gas buses without emission standards & 2 & 0.1 & 0.2 \\
\hline W2 & $\begin{array}{l}\text { Poor infrastructure for charging electric } \\
\text { vehicles }\end{array}$ & 5 & 0.1 & 0.5 \\
\hline W3 & $\begin{array}{l}\text { Higher price (up to } 4 \text { times) of green } \\
\text { vehicles }\end{array}$ & 4 & 0.15 & 0.6 \\
\hline W4 & $\begin{array}{l}\text { High cost of exploitation of hydrogen and } \\
\text { electric vehicles }\end{array}$ & 4 & 0.15 & 0.6 \\
\hline W5 & $\begin{array}{l}\text { Increased lithium demand } \\
\text { (costs and mining difficulty) }\end{array}$ & 3 & 0.05 & 0.15 \\
\hline W6 & $\begin{array}{l}\text { Problem with recycling lithium-ion } \\
\text { batteries }\end{array}$ & 3 & 0.05 & 0.15 \\
\hline W7 & $\begin{array}{l}\text { Short distance electric cars on a single } \\
\text { charge }\end{array}$ & 4 & 0.1 & 0.4 \\
\hline W8 & Long charging time & 4 & 0.1 & 0.4 \\
\hline W9 & No noise - danger to pedestrians & 2 & 0.05 & 0.1 \\
\hline W10 & $\begin{array}{l}\text { No cooperation between vehicle } \\
\text { manufacturers }\end{array}$ & 3 & 0.05 & 0.15 \\
\hline W11 & $\begin{array}{l}\text { Various types of chargers for charging } \\
\text { electric vehicles }\end{array}$ & 3 & 0.05 & 0.15 \\
\hline W12 & $\begin{array}{l}\text { Poor sales offer if some types of electric } \\
\text { cars and buses }\end{array}$ & 2 & 0.05 & 0.1 \\
\hline \multirow[t]{2}{*}{ W13 } & Very low sales of electric cars in Poland & 4 & 0.1 & 0.4 \\
\hline & & Sum & 1 & 3.5 \\
\hline
\end{tabular}

Table 3 Classification of opportunities of the green vehicles

\begin{tabular}{|c|c|c|c|c|}
\hline 운 & Opportunities & 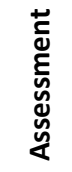 & $\begin{array}{l}\frac{ \pm}{5} \\
\frac{.000}{00} \\
3\end{array}$ & 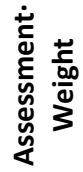 \\
\hline 01 & $\begin{array}{l}\text { Possibility to receive subsidies for green } \\
\text { vehicles }\end{array}$ & 5 & 0.1 & 0.5 \\
\hline $\mathrm{O} 2$ & $\begin{array}{l}\text { Possibility of new solutions, new } \\
\text { technologies }\end{array}$ & 4 & 0.1 & 0.4 \\
\hline $\mathrm{O} 3$ & Standardization of charging systems & 4 & 0.1 & 0.4 \\
\hline $\mathrm{O} 4$ & $\begin{array}{l}\text { Legal regulations favorable for the de- } \\
\text { velopment of electromobility }\end{array}$ & 4 & 0.1 & 0.4 \\
\hline 05 & Social pressure & 5 & 0.05 & 0.25 \\
\hline 06 & Poland's energy policy & 4 & 0.05 & 0.2 \\
\hline 07 & $\begin{array}{l}\text { Rapid progress in the production } \\
\text { of larger and cheap electric batteries }\end{array}$ & 5 & 0.1 & 0.5 \\
\hline 08 & $\begin{array}{l}\text { Development of public transport based } \\
\text { on green vehicles }\end{array}$ & 5 & 0.1 & 0.5 \\
\hline 09 & Increasing social awareness & 5 & 0.05 & 0.25 \\
\hline $\mathrm{O} 10$ & $\begin{array}{l}\text { Possibility to create own charging } \\
\text { stations up to } 22 \mathrm{~kW}\end{array}$ & 4 & 0.1 & 0.4 \\
\hline 011 & $\begin{array}{l}\text { Greater energy self-sufficiency } \\
\text { in the case of own RES }\end{array}$ & 4 & 0.1 & 0.4 \\
\hline \multirow[t]{2}{*}{012} & $\begin{array}{l}\text { Increasing the enterprise's credibility - } \\
\text { strengthening environmental missions }\end{array}$ & 5 & 0.05 & 0.25 \\
\hline & & Sum & 1 & 4.45 \\
\hline
\end{tabular}

Table 4 Classification of threats of the green vehicles

\begin{tabular}{|c|c|c|c|c|}
\hline 운 & Threats & 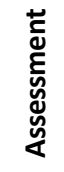 & $\begin{array}{l}\frac{n}{0} \\
\frac{0.00}{0} \\
3\end{array}$ & 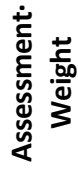 \\
\hline $\mathrm{T} 1$ & Price uncertainty & 3 & 0.15 & 0.45 \\
\hline $\mathrm{T} 2$ & Stricter emission standards & 5 & 0.15 & 0.75 \\
\hline T3 & $\begin{array}{l}\text { Reduction of the cost of financial support } \\
\text { for electromobility }\end{array}$ & 3 & 0.1 & 0.3 \\
\hline T4 & Large increase in electricity prices & 5 & 0.1 & 0.5 \\
\hline T5 & Unfavorable legal regulations & 4 & 0.1 & 0.4 \\
\hline T6 & Instability of fuel station infrastructure & 4 & 0.1 & 0.4 \\
\hline $\mathrm{T7}$ & $\begin{array}{l}\text { Lack of social acceptance due to the use } \\
\text { of new technologies }\end{array}$ & 4 & 0.1 & 0.4 \\
\hline T8 & $\begin{array}{l}\text { Difficult forms of crediting and leasing } \\
\text { the fleet }\end{array}$ & 3 & 0.1 & 0.3 \\
\hline T9 & $\begin{array}{l}\text { Unprofitable investments in new green } \\
\text { vehicles }\end{array}$ & 2 & 0.05 & 0.1 \\
\hline \multirow[t]{2}{*}{$\mathrm{T} 10$} & $\begin{array}{l}\text { Possible changes in energy taxation } \\
\text { (unclear legal provisions) }\end{array}$ & 4 & 0.05 & 0.2 \\
\hline & & Sum & 1 & 3.8 \\
\hline
\end{tabular}

The SWOT analysis allows determining the strategic position of the green vehicles. The strategy that should be taken is shown as the point in the coordinate system (Figure 1). To determine the coordinates of the point, the following calculation was made:

$$
\begin{aligned}
& Y=\mid \text { strengths }|-| \text { weaknesses } \mid=4.4-3.5=0.9 \\
& X=\mid \text { opportunities }|-| \text { threats } \mid=4.45-3.8=0.65
\end{aligned}
$$




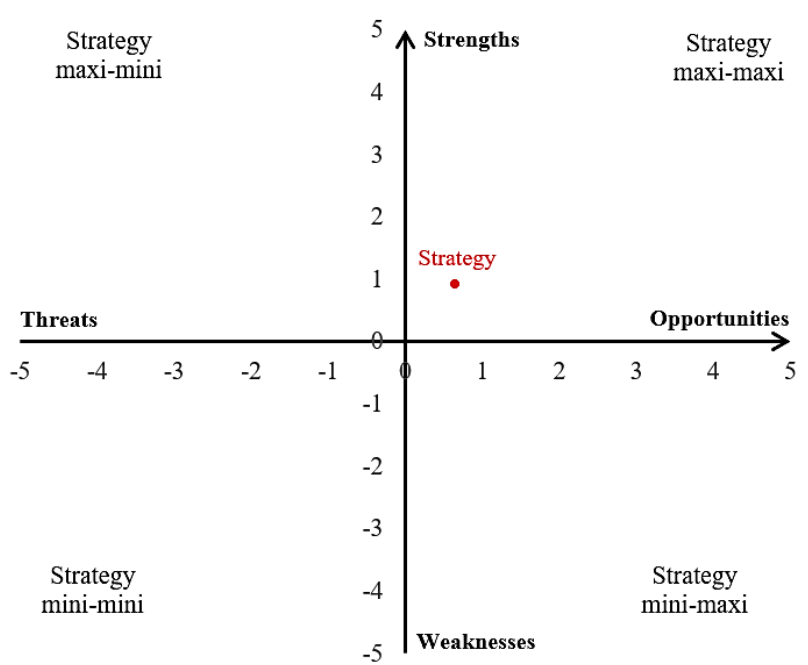

Fig. 1 Strategic position of the green vehicles

Based on the SWOT analysis, it can be noticed that the situation on the green vehicles market for the transport enterprises is characterized by the advantage of strengths over weaknesses and opportunities over threats. This means that the strategic position of the green vehicles is in the first quadrant of the Cartesian system, indicating a maxi-maxi (aggressive) strategy. In this strategy, strengths should be used to maximize the use of green vehicles. Opportunities that can help to maximize the use of strengths should be identified and used. Many factors contributed to these results of the analysis.

\section{DISCUSSION}

Among the strengths, the factors S3, S4, S6, S7 deserve special attention. These are all factors associated with the reduced environmental impact of green vehicles. This is what new solutions are created for. It is important from the point of view of the natural environment, which is one of the basic elements of the sustainable development. Only in this way it is possible to make the environment be guaranteed for future generations.

The problem with green vehicles, especially with electric vehicles, is mainly related to the poor infrastructure for charging electric vehicles (W2). Unfortunately, there is still a lot of work to do in this regard, which unfortunately has to be treated as the biggest weakness.

There are many opportunities for the enterprises that decide to purchase and use green vehicles. Firstly, due to the pro-ecological policy in many countries, there is a possibility to receive subsidies for green vehicles (01). There is a fair development of public transport based on green vehicles, the goal of which is as many electric vehicles as possible on the roads (08). It may also be influenced by the rapid progress in the production of larger and cheap electric batteries (07). There is also a second group of important opportunities, i.e. social pressure on environmental protection $(\mathrm{O} 5)$ resulting from increasing social awareness (09). By using green vehicles in transport, it is also possible to increase the enterprise's credibility - strengthening environmental missions (012). This group of factors is important from the environmental point of view in sustainable development.
Among the threats, the most important is Stricter emission standards (T2) and a large increase in electricity prices (T4). The first factor may mean that the vehicles that are currently referred to as green will soon stop being green due to the change of emission standards and another fleet replacement will be required, which unfortunately means new expenses. The large increase in electricity prices and the still unsatisfactory RES in Poland will also increase the costs of use of such vehicles. And yet, in order to achieve sustainable development, it must also include an economic element.

To take advantage of the current situation, certain elements of a maxi-maxi (aggressive) strategy have been identified. This strategy is presented in Table 5. Opportunities should be used to emphasize identified strengths. This study is the authors' discussion on the indicated strategy. This is expected to be a starting point for other authors to consider it in their future research, but it will also lead to a discussion about the future of green vehicles' use.

Table 5

Elements of the strategy

\begin{tabular}{|c|c|c|}
\hline & $\sqrt{\text { Strengths (S1-S11) }}$ & $\begin{array}{l}\text { Weaknesses } \\
\text { (W1-W13) }\end{array}$ \\
\hline $\begin{array}{l}\text { Opportunities } \\
\text { (01-012) }\end{array}$ & 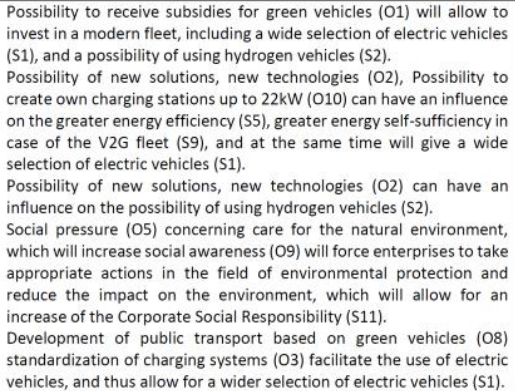 & \\
\hline $\begin{array}{l}\text { Threats } \\
\text { (T1-T10) }\end{array}$ & & $\begin{array}{c}\text { Suggested } \\
\text { aggressive } \\
\text { strategy }\end{array}$ \\
\hline
\end{tabular}

\section{CONCLUSIONS}

On the basis of the presented results of the SWOT analysis in the field of implementation of the green logistic strategy in transport companies, the following conclusions were drawn:

- $\quad$ subsidies for green vehicles would allow investing in a modern fleet, including a wide selection of electric vehicles, and a possibility of using hydrogen vehicles;

- new solutions (e.g. own charging stations) can have an impact on the greater energy efficiency and energy self-sufficiency;

- increase of social awareness would force enterprises to take appropriate actions in the field of environmental protection and reduce the impact on the environment;

- development of public transport based on green vehicles, standardization of charging systems facilitate the use of electric vehicles, and thus allow for a wider selection of electric vehicles.

Researches on the use of green transport should be widely conducted and discussed. It should be emphasized that this topic fits very well with SDG 7 of the sustainable development, concerning ensuring access to stable, sus- 
tainable and modern energy, with an emphasis on international cooperation in research on cleaner energy and technologies in this area, as well as the development of infrastructure and modernization of technologies enabling access to modern and sustainable energy services, including those used in transport.

\section{ACKNOWLEDGEMENTS}

Research and publication were financed by the statutory research fund of the Czestochowa University of Technology BS/PB-600/3010/2020.

\section{REFERENCES}

[1] B. Lux and B. Pfluger, "A supply curve of electricity-based hydrogen in a decarbonized European energy system in 2050," Applied Energy, vol. 269, no. 1882, p. 115011, 2020, doi: 10.1016/j.apenergy.2020.115011.

[2] "Communication from the commission to the European parliament, the council, the European economic and social committee and the committee of the regions: Sustainable and Smart Mobility Strategy - putting European transport on track for the future," https://ec.europa.eu/transport/sites/transport/files/legislation/com20200789.pdf.

[3] J.K. Szinai, C. J.R. Sheppard, N. Abhyankar, and A.R. Gopal, "Reduced grid operating costs and renewable energy curtailment with electric vehicle charge management," Energy Policy, vol. 136, no. 1, p. 111051, 2020, doi: 10.1016/j.enpol.2019.111051.

[4] D. Danalakshmi, R. Gopi, A. Hariharasudan, I. Otola, and Y. Bilan, "Reactive Power Optimization and Price Management in Microgrid Enabled with Blockchain," Energies, vol. 13 , no. 23 , p. 6179 , 2020, doi: 10.3390/en13236179.

[5] A. Gaur and D.A. Vazquez-Brust, "Sustainable Development Goals: Corporate Social Responsibility? A Critical Analysis of Interactions in the Construction Industry Supply Chains Using Externalities Theory," vol. 7, pp. 133-157, doi: 10.1007/978-3-030-15066-2_8.

[6] M. Krynke, "Application of linear programming in supply chain management in the foundry," Proceedings $29^{\text {th }}$ International Conference on Metallurgy and Materials, Brno, Czech Republic, EU, May 20-22, 2020, pp. 1280-1286, doi: 10.37904/metal.2020.3648.

[7] J. Grabara, "Sustainable development - Never fulfilled dream," Quality - Access to Success, vol. 20, pp. 565-570, 2019.

[8] J. Grabara, M. Dabylova, and G. Alibekova, "Impact of legal standards on logistics management in the context of sustainable development," Acta Logistica, vol. 7, no. 1, pp. 3137, 2020, doi: 10.22306/al.v7i1.155.

[9] A. Mesjasz-Lech and P. Michelberger, "Sustainable Waste Logistics and the Development of Trade in Recyclable Raw Materials in Poland and Hungary," Sustainability, vol. 11, no. 15 , p. 4159,2019 , doi: $10.3390 /$ su11154159.

[10] S. Lazar, D. Klimecka-Tatar, and M. Obrecht, "Sustainability Orientation and Focus in Logistics and Supply Chains," Sustainability, vol. 13 , no. 6 , p. 3280, 2021, doi: 10.3390/su13063280.

[11] M. Drljača, S. Petar, M. Raad, and I. Štimac, "The role and position of Airport City in the Supply Chain," Production Engineering Archives, vol. 26, no. 3, pp. 104-109, 2020, doi: 10.30657/pea.2020.26.21.
[12] D. Klimecka-Tatar and M. Niciejewska, "Small-sized enterprises management in the aspect of organizational culture," Revista Gestão \& Tecnologia - Journal of Management and Technology, vol. 1, pp. 4-24, 2021, doi: 10.20397/2177-6652/2021.v21i1.2023.

[13] M. Suchacka, "Corporate Digital Responsibility - A New Dimension of the Human - Technology Relations," System Safety: Human - Technical Facility - Environment, vol. 2, no. 1, pp. 1-8, 2020, doi: 10.2478/czoto-2020-0001.

[14] K. Teplická and S. Hurná, "New Approach of Costs of Quality According their Trend of During Long Period in Industrial Enterprises in SMEs," Management Systems in Production Engineering, vol. 29, no. 1, pp. 20-26, 2021, doi: 10.2478/mspe-2021-0003.

[15] M. Ingaldi and D. Klimecka-Tatar, "People's Attitude to Energy from Hydrogen - From the Point of View of Modern Energy Technologies and Social Responsibility," Energies, vol. 13, no. 24, p. 6495, 2020, doi: 10.3390/en13246495.

[16] M. Krynke and K. Mielczarek, "Applications of linear programming to optimize the cost-benefit criterion in production processes," MATEC Web Conf., vol. 183, p. 4004, 2018, doi: $10.1051 /$ matecconf/201818304004.

[17] M. Ingaldi and R. Ulewicz, "Problems with the Implementation of Industry 4.0 in Enterprises from the SME Sector," Sustainability, vol. 12 , no. 1 , p. 217, 2020, doi: 10.3390/su12010217.

[18] M. Ingaldi and R. Ulewicz, "How to Make E-Commerce More Successful by Use of Kano's Model to Assess Customer Satisfaction in Terms of Sustainable Development," Sustainability, vol. 11, no. 18, p. 4830, 2019, doi: 10.3390/su11184830.

[19] J. Żywiołek, "Monitoring of information security system elements in the metallurgical enterprises," MATEC Web Conf., vol. 183, p. 1007, 2018, doi: 10.1051/matecconf/201818301007.

[20] R. Ulewicz and L.V. Lazar, "The Effect of Lean Tools on the Safety Level in Manufacturing Organisations," System Safety: Human - Technical Facility - Environment, vol. 1, no. 1, pp. 514-521, 2019, doi: 10.2478/czoto-2019-0066.

[21] V. Tkachenko, M. Klymchuk, and I. Tkachenko, "Recursive and Convergence Methodology of the Investment Management of the Enterprise Digitalization Processes," Management Systems in Production Engineering, vol. 29, no. 1, pp. 14-19, 2021, doi: 10.2478/mspe-2021-0002.

[22] D. Klimecka-Tatar and M. Ingaldi, "How to indicate the areas for improvement in service process - the Knowledge Management and Value Stream Mapping as the crucial elements of the business approach," Revista Gestão \& Tecnologia - Journal of Management and Technology, vol. 20 , no. 2, pp. 52-74, 2020, doi: 10.20397/21776652/2020.v20i2.1878.

[23] M. Starostka-Patyk, P. Tomski, and M. Zawada, "Diversity Management as a Part of Corporate Social Responsibility Policy," Procedia Computer Science, vol. 65, pp. 10381045, 2015, doi: 10.1016/j.procs.2015.09.055.

[24] L. Bloice and S. Burnett, "Barriers to knowledge sharing in third sector social care: a case study," Journal of Knowledge Management, vol. 20, no. 1, pp. 125-145, 2016, doi: 10.1108/JKM-12-2014-0495.

[25] N. Carvalho and I. Gomes, "Knowledge Sharing between Enterprises of the Same Group," International Journal of Knowledge Management, vol. 13, no. 1, pp. 34-52, 2017, doi: 10.4018/IJKM.2017010103. 
[26] M. Matuszny, "Building decision trees based on production knowledge as support in decision-making process," Production Engineering Archives, vol. 26, no. 2, pp. 36-40, 2020, doi: $10.30657 /$ pea.2020.26.08.

[27] M. Tutak, J. Brodny, D. Siwiec, R. Ulewicz, and P. Bindzár, "Studying the Level of Sustainable Energy Development of the European Union Countries and Their Similarity Based on the Economic and Demographic Potential," Energies, vol. 13 , no. 24 , p. 6643,2020 , doi: $10.3390 /$ en13246643.

[28] M. Knez and M. Obrecht, "Policies for Promotion of Electric Vehicles and Factors Influencing Consumers' Purchasing Decisions of Low Emission Vehicles," Journal of Sustainable Development of Energy, Water and Environment Systems, vol. 5, no. 2, pp. 151-162, 2017, doi: 10.13044/j.sdewes.d5.0139.

[29] B.K. Sovacool, J. Kester, L. Noel, and G. Zarazua de Rubens, "Actors, business models, and innovation activity systems for vehicle-to-grid (V2G) technology: A comprehensive review," Renewable and Sustainable Energy Reviews, vol. 131, no. 3, p. 109963, 2020, doi: 10.1016/j.rser.2020.109963.

[30] M. Vatsa, M. Dharwal, P. Sharma, and A. Kumar Srivastava, "Green vehicles more a necessity than an option," Materials Today: Proceedings, vol. 88, no. 1, p. 107, 2020, doi: 10.1016/j.matpr.2020.09.054.

[31] N. Mohammadzadeh, S.H. Zegordi, and E. Nikbakhsh, "Pricing and free periodic maintenance service decisions for an electric-and-fuel automotive supply chain using the total cost of ownership," Applied Energy, vol. 288, p. 116471, 2021, doi: 10.1016/j.apenergy.2021.116471.

[32] S. Bobeth and I. Kastner, "Buying an electric car: A rational choice or a norm-directed behavior?," Transportation Research Part F: Traffic Psychology and Behaviour, vol. 73, no. 4, pp. 236-258, 2020, doi: 10.1016/j.trf.2020.06.009.

[33] L. Rotaris, M. Giansoldati, and M. Scorrano, "The slow uptake of electric cars in Italy and Slovenia. Evidence from a stated-preference survey and the role of knowledge and environmental awareness," Transportation Research Part A: Policy and Practice, vol. 144, no. 2, pp. 1-18, 2021, doi: 10.1016/j.tra.2020.11.011.

[34] M.M. Helms and J. Nixon, "Exploring SWOT analysis where are we now?," Journal of Strategy and Mgt, vol. 3, no. 3, pp. 215-251, 2010, doi: 10.1108/17554251011064837.

[35] M.C. Bonfante, J.P. Raspini, I.B. Fernandes, S. Fernandes, L. M.S. Campos, and O.E. Alarcon, "Achieving Sustainable Development Goals in rare earth magnets production: A review on state of the art and SWOT analysis," Renewable and Sustainable Energy Reviews, vol. 137, no. 2, p. 110616, 2021, doi: 10.1016/j.rser.2020.110616.

\section{Dorota Klimecka-Tatar}

ORCID ID: 0000-0001-6212-6061

Częstochowa University of Technology

Faculty of Management

ul. Dąbrowskiego 69, 42-201 Częstochowa, Poland

e-mail: d.klimecka-tatar@pcz.pl

\section{Manuela Ingaldi}

ORCID ID: 0000-0002-9793-6299

Częstochowa University of Technology

Faculty of Management

ul. Dąbrowskiego 69, 42-201 Częstochowa, Poland

e-mail: manuela.ingaldi@wz.pcz.pl
[36] M.J. Ruá, P. Huedo, M. Cabeza, B. Saez, and R. Agost-Felip, "A model to prioritise sustainable urban regeneration in vulnerable areas using SWOT and CAME methodologies," Journal of Housing and the Built Environment, vol. 43, no. 1, p. 187, 2021, doi: 10.1007/s10901-020-09813-w.

[37] M. Obrecht, Y. Kazancoglu, and M. Denac, "Integrating Social Dimensions into Future Sustainable Energy Supply Networks," International journal of environmental research and public health, vol. 17, no. 17, 2020, doi: 10.3390/ijerph17176230.

[38] M. Obrecht, R.E. Haddad, R.A. Elbary, R.K. Lukman, and M. Rosi, "Promoting Sustainable and Circular Plastics Use in Egipt with Implementation of Ecodesign Principles," System Safety: Human - Technical Facility - Environment, vol. 1, no. 1, pp. 441-448, 2019, doi: 10.2478/czoto-2019-0057.

[39] M. Knez, B. Jereb, E. Jadraque Gago, J. Rosak-Szyrocka, and M. Obrecht, "Features influencing policy recommendations for the promotion of zero-emission vehicles in Slovenia, Spain, and Poland," Clean technologies and environmental policy, pp. 1-16, 2020, doi: 10.1007/s10098-02001909-9.

[40] D. Klimecka-Tatar and O. Matevž, "The Level of Occupational Health and Safety in European Enterprises Providing Transport and Logistics Services in Terms of Quality Management Principles," Multidisciplinary Aspects of Production Engineering, vol. 3, no. 1, pp. 394-404, 2020, doi: 10.2478/mape-2020-0034.

[41] P. Bajdor, "Comparison between sustainable development concept and green logistics - The Literature Review," Polish Journal of Management Studies, vol. 5, pp. 236-244, 2012.

[42] B. Balon and M. Roszak, "Cost-quantitative analysis of noncompliance in the internal logistics process," Production Engineering Archives, vol. 26, no. 2, pp. 60-66, 2020, doi: 10.30657/pea.2020.26.13.

[43] T. D. C. Le, D. D. Nguyen, J. Oláh, and M. Pakurár, “Optimal vehicle route schedules in picking up and delivering cargo containers considering time windows in logistics distribution networks: A case study," Production Engineering Archives, vol. 26, no. 4, pp. 174-184, 2020, doi: 10.30657/pea.2020.26.31.

\author{
Matevž Obrecht \\ ORCID ID: 0000-0001-8301-7382 \\ University of Maribor \\ Faculty of Logistics \\ Maribor, Slovenia \\ e mail: matevz.obrecht@um.si
}

